\title{
RANCANG BANGUN SISTEM INFORMASI PENJUALAN PADA TOKO BANGUNAN UD.ZAM-ZAM BERBASIS DESKTOP
}

\author{
Yoga Alamsyah ${ }^{1}$, Forkas Tiroy Santos B ${ }^{2}$ \\ ${ }^{1,2}$ Teknik Informatika, Fakultas Teknik dan Ilmu Komputer, Universitas Indraprasta PGRI \\ Jalan Raya Tengah No 80, Kelurahan Gedong, Pasar Rebo, Jakarta Timur \\ yogaalamsyah27@gmail.com ${ }^{1}$,ftsb4unindra@gmail.com ${ }^{2}$
}

\begin{abstract}
ABSTRAK
Perkembangan teknologi dan informasi di zaman sekarang ini tentunya tidak dapat dihindari lagi kemajuannya. Banyak instansi sudah beralih dari sistem konvensional menjadi sistem yang sudah terkomputerisasi. Tujuan penelitian adalah untuk membuat sistem informasi penjualan toko bangunan menjadi lebih cepat dan juga mempermudah dalam pencarian data barang yang lebih akurat di Toko Bangunan UD.Zam-Zam yang sebelumnya belum menggunakan cara yang terkomputerisasi yaitu dengan mencatat di sebuah buku dan masih membutuhkan waktu yang cukup lama dalam hal pendataan barang dan perhitungan transaksi. Sekarang bisa dengan mudah dalam melakukan pendataan barang dan perhitungan transaksi karena data dapat disimpan dalam database sehingga memudahkan admin dalam melakukan pendataan barang dan petugas toko dalam melakukan perhitungan transaksi pada Toko Bangunan UD.Zam-Zam. Metodelogi yang digunakan untuk merancang Sistem Informasi ini adalah dengan metode analisis data dan observasi lapangan. Selain itu penyusun juga menggunakan metode wawancara untuk mendapatkan data lebih lengkap. Metode pengembangan sistem menggunakan metode waterfall. Hasil penelitian diperoleh bahwa aplikasi Sistem Informasi Penjualan ini dapat mempermudah petugas toko dalam melakukan pekerjaannya.
\end{abstract}

Kata Kunci: Sistem Informasi, Penjualan, Desktop

\begin{abstract}
The development of technology and information in today's era is certainly unavoidable. Many agencies switch from conventional systems to computerized systems. The purpose of the research is to make the store sales information system faster and easier to search for more accurate item data at the UD. Zam-Zam Building Store has not used an integrated method, namely recording in a sufficient book, and still takes a long time. long. takes a long time in terms of collecting data on goods and calculating transactions. Now it is possible to collect data on goods and calculate transactions because data can be stored in a database, making it easier for admins to collect data on goods and officers in calculating transactions at the UD. Zam-Zam Building Store. The methodology used to design this Information System is the method of data analysis and field observation. In addition, the manufacture also uses the interview method to obtain more data. The system development method uses the waterfall method. The results showed that the Sales Information System application could make it easier for store clerks to do their jobs.
\end{abstract}

Key Word: Information Systems, Sales, Desktop

\section{PENDAHULUAN}

Perkembangan teknologi dan informasi di zaman sekarang ini tentunya tidak dapat dihindari lagi kemajuannya. Banyak instansi sudah beralih dari sistem konvensional menjadi terkomputerisasi. Dengan sistem informasi ini menjadikan pengolahan data dan informasi menjadi lebih optimal dan efisien. Dengan adanya sistem informasi yang terkomputerisasi ini sangat memudahkan pemilik toko dan pegawai dalam mengelola data, stok barang, transaksi serta dalam pembuatan laporan.

Toko bangunan UD.Zam-Zam merupakan sebuah usaha yang bergerak pada penjualan bahan bangunan dan alat listrik. Toko ini menjual berbagai bahan bangunan seperti pasir, semen, macam - macam kayu, paku, cat, besi pondasi, sekop, palu dan sebagainya. Toko bangunan UD.Zam-Zam berdiri pada September 2005 didirikan oleh Bapak Darmanto, Toko bangunan ini berada di daerah Kalisari, Kota Jakarta Timur.

Menurut pemilik toko, pengolahan data seperti pencatatan pencatatan barang dan penjualan, data pelanggan dan melihat data barang masih menggunakan cara manual dengan mencatat di buku dan juga faktur sebagai bukti pembelian. Stok barang yang belum tercatat menimbulkan laporan 
keuangan toko yang tidak sesuai dalam penghitungan. Menggunakan cara manual dapat menimbulkan masalah lain yaitu terjadinya ketidak efesienan waktu dan biaya toko. Maka dengan itu penulis dalam hal permasalahan diatas ingin mengangkat "Rancang Bangun Sistem Informasi Penjualan Pada Toko Bangunan UD.ZamZam Berbasis Desktop".

Rancang merupakan rangkaian proses yang digunakan untuk menafsirkan perkembangan analisa dari sistem ke dalam bahasa pemrograman untuk dideskripsikan dengan detail bagaimana komponen-komponen sistem diimplementasikan (Prasetya, 2020). Bangun adalah suatu kegiatan membuat sistem yang baru ataupun mengganti dan memperbaiki sistem yang sudah ada secara keseluruhan maupun sebagian(Prasetya, 2020). Maka rancang bangun merupakan suatu istilah umum untuk membuat atau mendesain suatu objek mulai dari awal proses sampai akhir proses pembuatan(Prasetya, 2020).

Perancangan sistem adalah awal untuk menentukan proses data yang dibutuhkan dalam membuat atau mengembangkan sistem yang baru. Perancangan sistem memiliki tujuan utama yaitu untuk memenuhi kebutuhan pemakai sistem yang baru serta untuk mendapatkan gambaran yang jelas dan perancangan yang lengka(Atmaja, 2020).

Informasi merupakan data yang sudah diproses menjadi informasi yang dapat memberikan manfaat bagi penerimanya, informasi tersebut merupakan nilai yang dapat dimengerti secara bersama-sama dalam pengambilan keputusan saat ini dan yang akan datang (Novienty, 2016).

Penjualan adalah sebuah proses yaitu kebutuhan pembeli dan kebutuhan penjual dipenuhi, melalui pertukaran informasi dan kepentingan(Solihin \& Nusa, 2017). Pelanggan merupakan seseorang yang secara berulang kali datang ke tempat yang sama hanya untuk memenuhi keinginan pribadinya dengan cara membeli produk atau jasa yang harus dimilikinya(Yanniar Afriendari, 2016). adalah refresentasi grafik yang menggambarkan aliran informasi dan transformasi informasi yang diaplikasikan sebagai data yang mengatur dari masukan (input) dan keluaran (output). DFD tidak sesuai untuk memodelkan sistem yang menggunakan pemograman berorientasi objek(ANDINI, 2016).

Entitiy Relationship Diagram (ERD) adalah tipe awal basis data yang dikembangkan dengan dasar teori himpunan dalam bidang matematika untuk tipe model basis data relasional(KUSUMA, 2019). ERD memiliki beberapa aliran notasi seperti notasi Chen (dikembangkan oleh Peter Chen). Barker (dikembangkan oleh Richard Barker, Ian Palmer, Harry Ellis), notasi Crow's Foot, dan beberapa notasi lain. Namun yang banyak digunakan adalah notasi dari Chen(Sukamto \& Shalahuddin, 2018).

SQL adalah bahasa yang sangat basic untuk mengakses database. Bahasa ini pada mulanya dikembangkan oleh IBM, namun telah diadopsi dan digunakan sebagai standar industri(Sesunan, 2017).

Tujuan dari penelitian pada Toko UD.ZamZam adalah untuk memudahkan pemilik toko dalam melakukan proses penjualan dan meminimalisir kesalahan pada saat pembuatan laporan penjualan dan mengolah data transaksi. Mengurangi terjadinya kekeliruan dalam perhitungan barang, untuk mempercepat pemilik melihat stok barang dan mengurangi kesalahan dalam penjualan dengan menggunakan aplikasi Toko UD.Zam-Zam.

\section{METODE PENELITIAN}

Pada penelitian ini, penulis menggunakan metode deskriptif dimana metode yang membahas suatu masalah dengan menjelaskan, menafsirkan dan menulis suatu keadaan atau peristiwa kemudian dianalisis serta mengambil kesimpulan umum dari permasalahan yang dibahas, atau suatu penelitian yang bertujuan untuk menggambarkan dan melukiskan mengenai fakta-fakta atau keadaan yang ada di dalam perusahaan. 
Metode Pengumpulan Data

Metode pengumpulan data yang dilakukan penulis untuk mendapatkan data informasi untuk mendukung penyempurnaan hasil dari penelitian ini antara lain:

\section{Wawancara}

Wawancara adalah pengumpulan data dengan cara tanya jawab secara langsung oleh pihak-pihak yang berhubungan dengan observasi penelitian yaitu pemilik toko bangunan(Sipahutar, 2017).

Wawancara dilakukan untuk memperoleh data dari narasumber yaitu bapak Muhammad Subhi selaku pengelola toko UD.Zam-Zam. Dalam wawancara ini peneliti menanyakan beberapa hal yang terkait dengan pengelolaan Toko Bangunan. Metode ini digunakan untuk memperoleh informasi dan data pada Toko Bangunan "UD.Zam-Zam".

2. Observasi

Observasi adalah suatu kegiatan dengan mengamati dan mendokumentasikan halhal yang terjadi selama kegiatan berlangsung. Pada saat dilakukan kegiatan, secara bersamaan juga dilakukan pengamatan tentang semua proses yang berlangsung(MSi, 2012).

\section{HASIL DAN PEMBAHASAN}

Berdasarkan masalah-masalah yang dihadapi dalam penjualan toko bangunan UD.ZamZam, maka penulis memberikan solusi penyelesaian masalah yaitu :

1. Perancangan sistem informasi penjualan berbasis desktop semoga dapat menghasilkan informasi yang cepat, tepat, dan akurat

2. Data barang, data petugas toko, data penjualan, data stok barang serta riwayat transaksi dapat disimpan ke dalam database dan mempermudah dalam melakukan pengecekan karena sudah ada dalam databse.

3. Merancang sistem penjualan toko bangunan yang dibutuhkan mudah dipahami oleh pengguna agar dapat digunakan oleh petugas, baik yang mahir komputerisasi maupun tidak

Dalam membangun sistem informasi yang kompleks membutuhkan metode - metode atau paradigma pengembangan yang mampu membantu menganalisis dan mendisain secara lebih detail sehingga informasi yang dihasilkan lebih akurat. Dalam penyusunan penelitian ini, penulis menggunakan metode pendekatan kualitatif deskriptif, yaitu mengumpulkan data kemudian menganalisanya serta memaparkan hasil pengamatan yang terdapat di lapangan.

Langkah-Langkah pengembangan sistem : Langkah-langkah pengembangan sistem yang digunakan penulis dalam rancang bangun sistem informasi penjualan pada toko UD.Zam-Zam berbasis desktop dengan menggunakan metode pengembang model waterfall. Waterfall atau air terjun adalah model yang dikembangkan untuk pengembangan perangkat lunak, membuat perangkat lunak, model berkembang secara sistematis dari satu tahap ke tahap lain dalam metode seperti air terjun.

Tahapan pengembangan model waterfall adalah sebagai berikut :

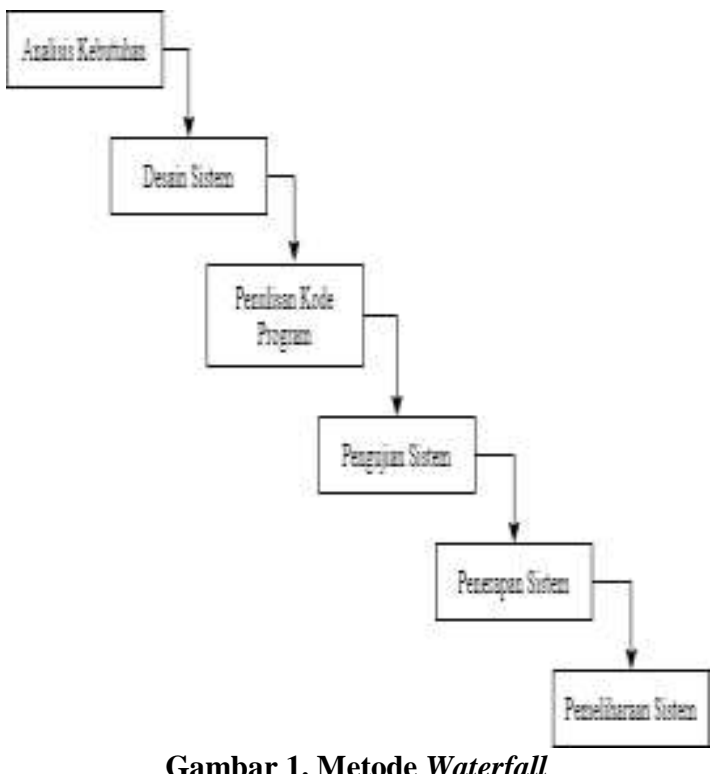

Gambaran dari sistem yang diusulkan pada Toko bangunan UD.Zam-Zam adalah sebagai berikut:

\section{Diagram Alir Data (DAD) Sistem Diusulkan \\ Diagram Konteks}

Berikut ini merupakan diagram Alir Data (DAD) sistem yang diusulkan akan digunakan pada Toko Bangunan UD.ZamZam. 


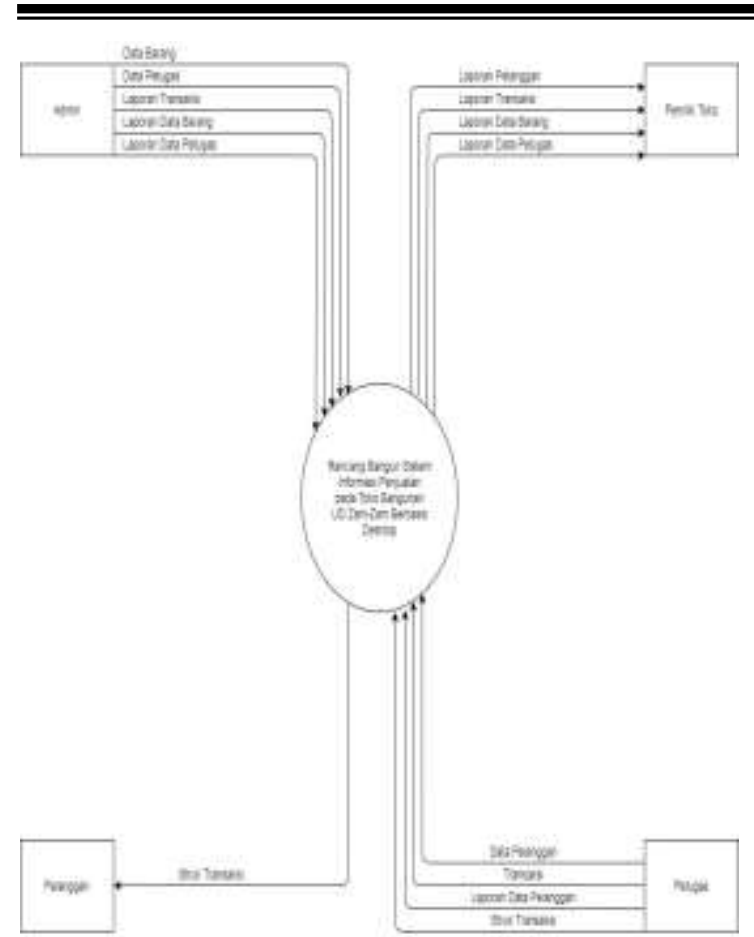

Gambar 2. Diagram Konteks Sistem yang Diusulkan

\section{Entity Relationship Diagram (ERD)}

Berikut ini merupakan Entity Relationship Diagram (ERD) yang digunakan pada Toko Bangunan UD.Zam-Zam

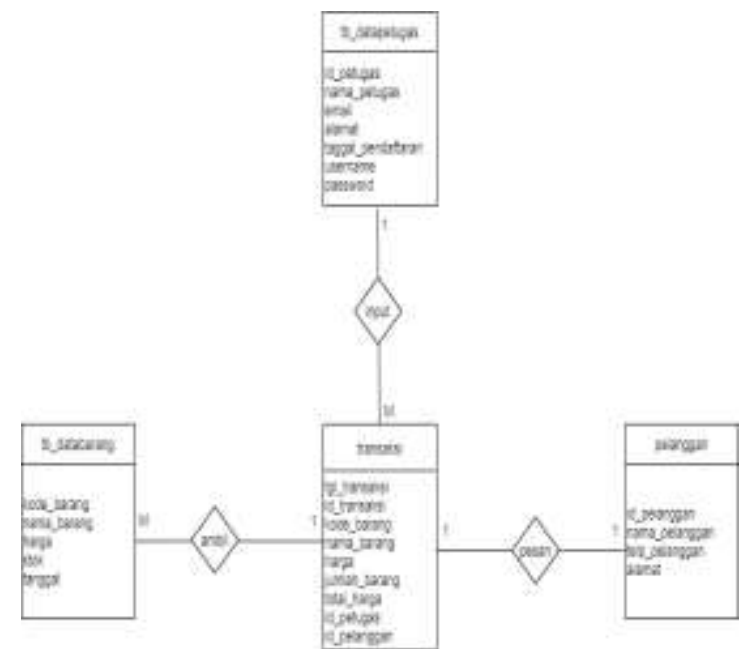

Gambar 3. Entity Relationship Diagram (ERD)

Berikut ini adalah tampilan layar dan hasil percobaan pada software program yang dibuat dengan bahasa pemrograman Java.

\section{Tampilan Layar Aplikasi Penjualan Toko Bangunan UD.Zam-Zam}

Berikut ini merupakan tampilan layar pada aplikasi penjualan toko bangunan UD.ZamZam.
Tampilan Menu Login

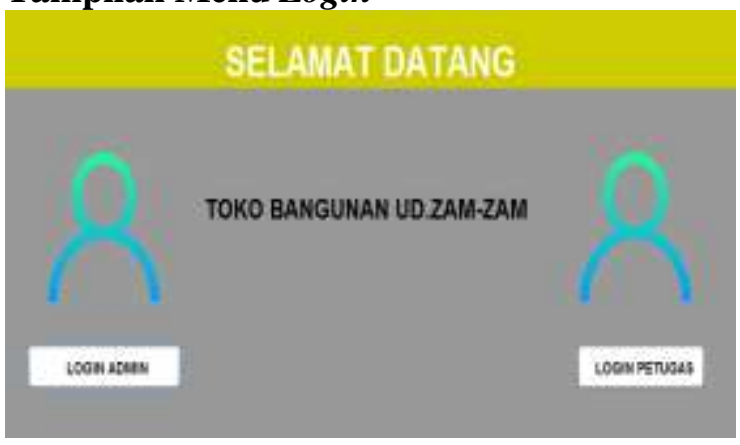

Gambar 4. Tampilan Layar Login

Pada tampilan layar ini terdapat login admin dan login petugas untuk login. Menu login admin dan petugas berbeda untuk lebih terjaganya data barang dan transaksi penjualan.

\section{Tampilan Login Admin}

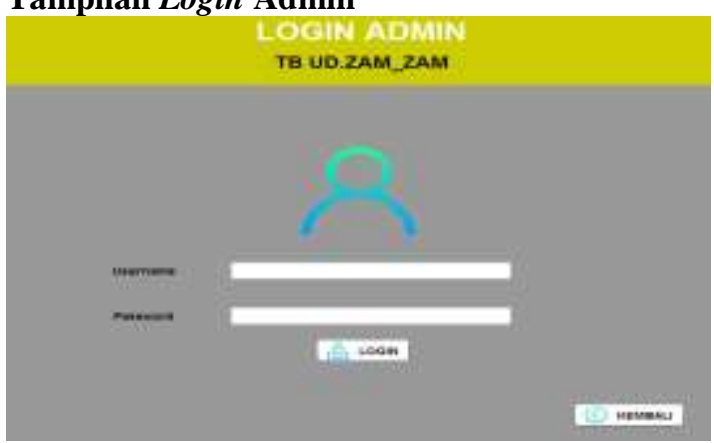

Gambar 5. Tampilan Layar Login Admin

Pada tampilan login admin ini admin akan login untuk masuk kedalam data barang,data petugas, dan melihat riwayat transaksi penjualan serta mencetak laporan data barang, data petugas, dan laporan transaksi penjualan.

\section{Tampilan Login Petugas}

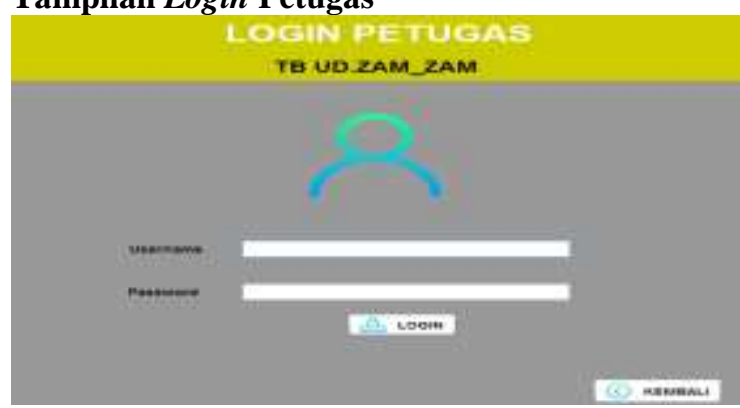

Gambar 6. Tampilan Layar Login Petugas

Pada tampilan login petugas ini petugas akan login untuk masuk kedalam data pelanggan,data transaksi, melihat data persediaan barang, dan riwayat transaksi.

\section{Tampilan Menu Admin}




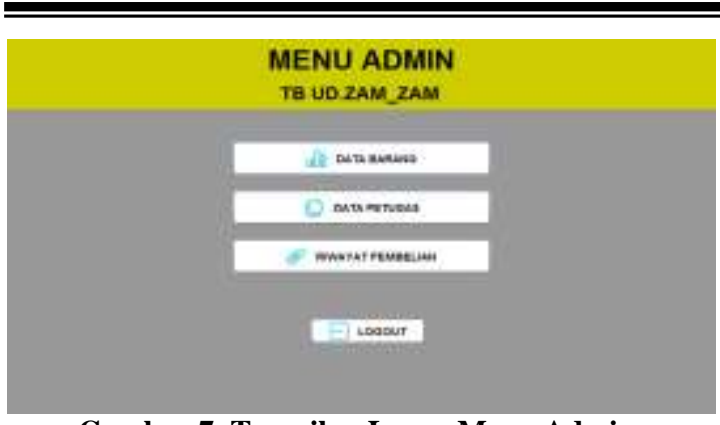

Gambar 7. Tampilan Layar Menu Admin

Rancang layar ini hanya bisa di akses bila admin sudah melewati proses login yang sebelumnya sudah berhasil dan tidak salah dalam memasukkan username atau password maka akan mengakses pada bagian menu admin. Admin dapat mengakses data barang,data petugas, dan riwayat pembelian.

\section{Tampilan Menu Petugas}

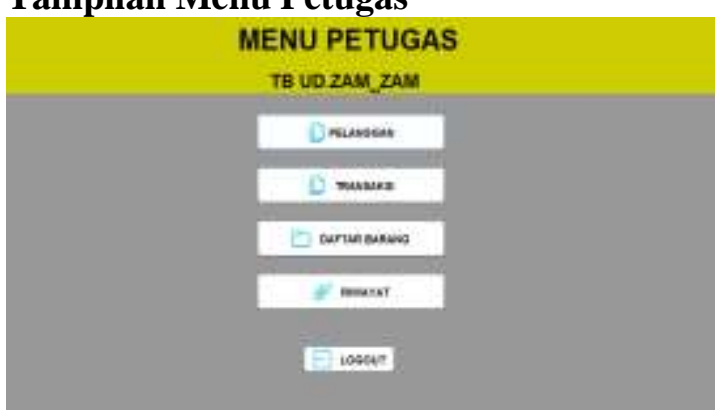

Gambar 8. Tampilan Layar Menu Petugas

Rancang layar ini hanya bisa di akses bila petugas sudah melewati proses login yang sebelumnya sudah berhasil dan tidak salah dalam memasukkan username atau password maka akan mengakses pada bagian menu petugas.

Admin dapat mengakses data barang,data petugas, dan riwayat pembelian.

\section{Tampilan Data Barang}

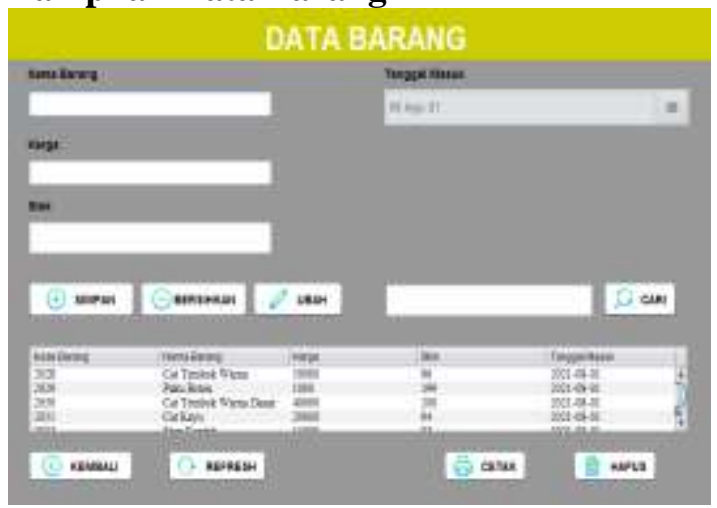

Gambar 9. Tampilan Layar Data Barang

Pada tampilan layar ini berfungsi untuk admin menginput data barang masuk dan mencetak laporan data barang. Maka dengan hal ini diharapkan akan terjadinya berkurangnya kesalahan dalam perhitungan data barang serta mempermudah dalam melakukan laporan data barang.

\section{Tampilan Data Petugas}

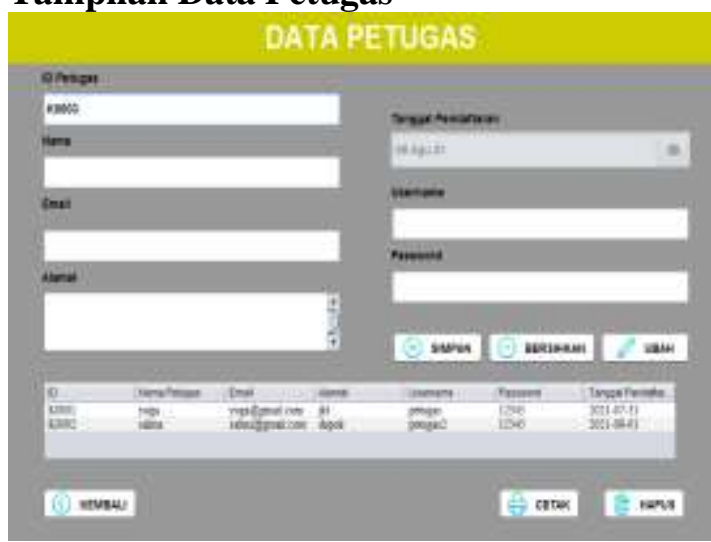

Gambar 10. Tampilan Layar Data Petugas

Pada tampilan layar ini berfungsi untuk admin menginput data petugas dan mencetak laporan data petugas. Maka dengan hal ini diharapkan akan mempermudah admin dalam mendata petugas yang bekerja didalam toko.

\section{Tampilan Layar Riwayat Pembelian}

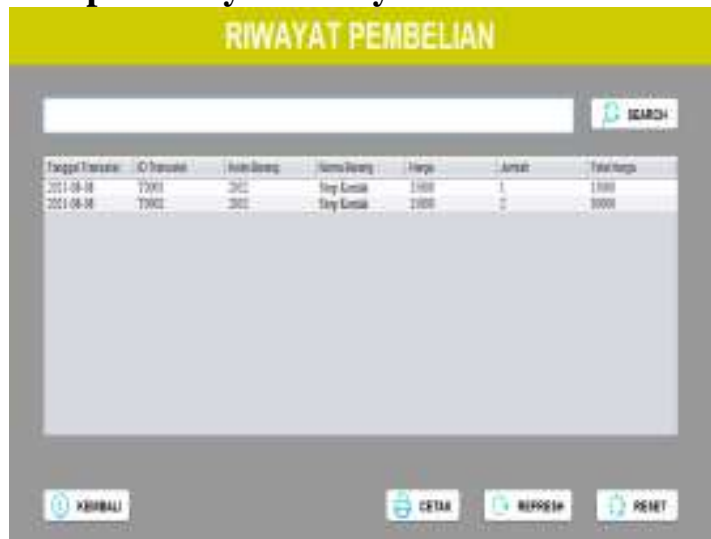

Gambar 11. Tampilan Layar Riwayat Pembelian

Pada tampilan layar ini berfungsi untuk admin mencetak laporan riwayat transaksi dan juga dapat mereset seluruh data riwayat transaksi. Maka dengan hal ini diharapkan akan terjadinya berkurangnya kesalahan dalam perhitungan riwayat transaksi dan mempermudah pemilik toko dalam melihat riwayat transaksi yang dilakukan. 


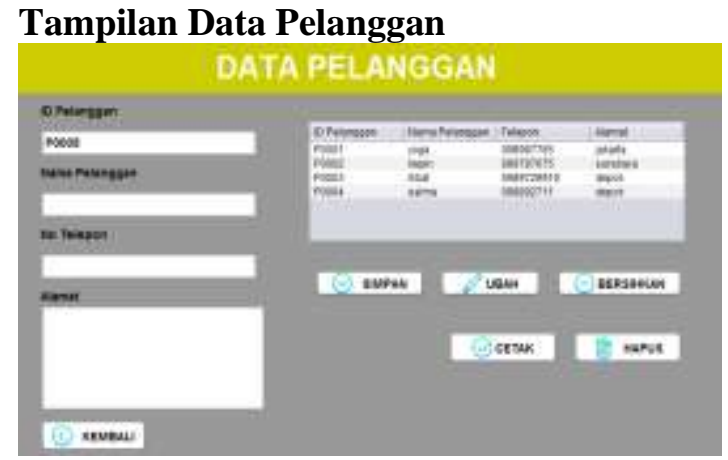

Gambar 12. Tampilan Data Pelanggan

Pada tampilan layar ini berfungsi untuk petugas melakukan input data pelanggan dan mencetak laporan data pelanggan kemudian diserahkan kepada pemilik toko. Maka dengan hal ini diharapkan mempermudah petugas dalam mendata pelanggan yang ada dan membuat laporan data pelanggan.

\section{Tampilan Data Transaksi}

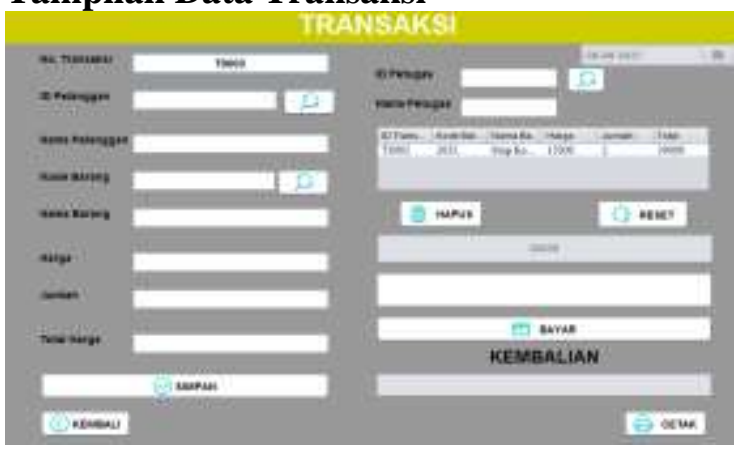

Gambar 13. Tampilan Data Transaksi

Pada tampilan layar ini berfungsi untuk petugas melakukan transaksi penjualan kepada pelanggan. Maka dengan hal ini diharapkan akan terjadinya berkurangnya kesalahan dalam perhitungan data transaksi dan mempermudah petugas dalam melakukan transaksi yang dilakukan.

\section{Tampilan Daftar Barang}

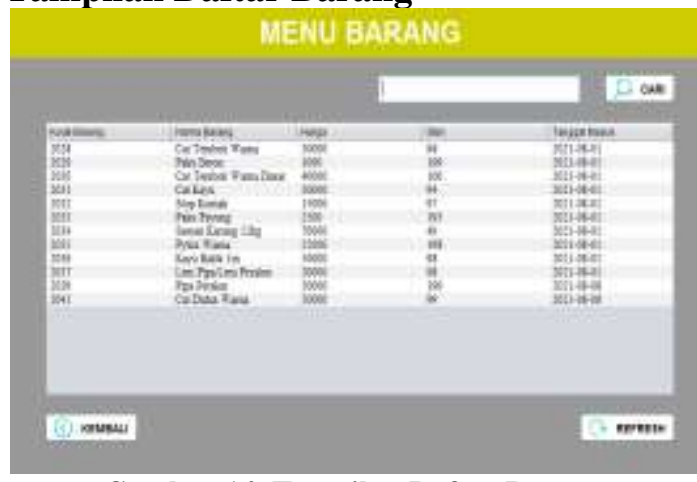

Gambar 14. Tampilan Daftar Barang
Pada tampilan layar ini berfungsi untuk petugas mengecek stok barang yang ada. Maka dengan hal ini diharapkan akan mempermudah petugas dalam melihat persediaan barang.

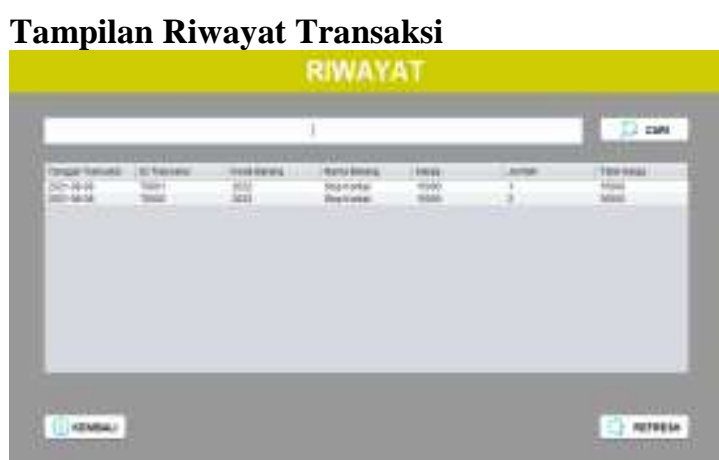

Gambar 15. Tampilan Riwayat Transaksi

Pada tampilan layar ini berfungsi untuk petugas melihat riwayat transaksi. Maka dengan hal ini diharapkan akan mempermudah petugas untuk melihat riwayat penjualan yang sudah dilakukan.

\section{Tampilan Laporan Data Barang}

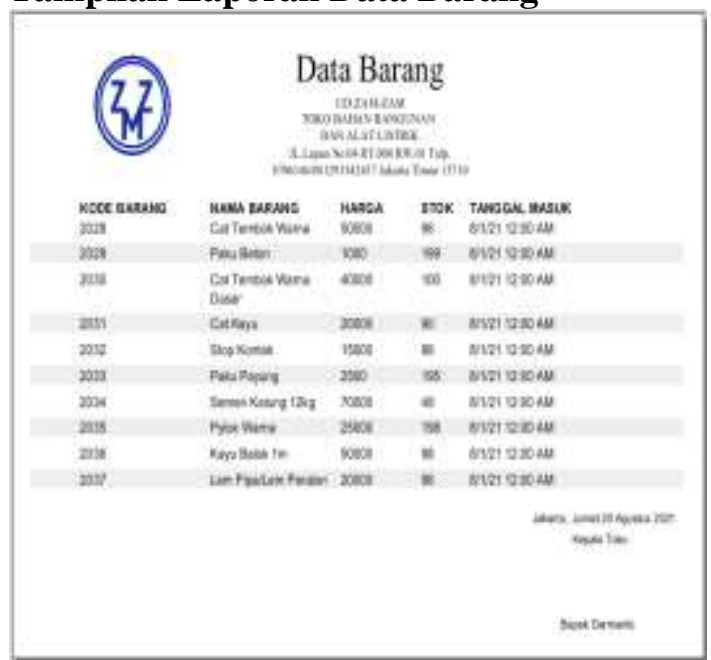

Gambar 16. Tampilan Laporan Data Barang

Laporan data barang ini digunakan untuk melihat data barang yang ada pada Toko Bangunan UD.Zam-Zam. Dalam laporan data barang ini terdapat logo, nama barang, kode barang, harga, stok, tanggal masuk barang, tanggal pembuatan laporan dan nama dari pemilik toko itu sendiri. Laporan data barang ini nantinya akan disimpan oleh admin sebagai berkas laporan yang telah dikeluarkan. 
Tampilan Laporan Data Petugas

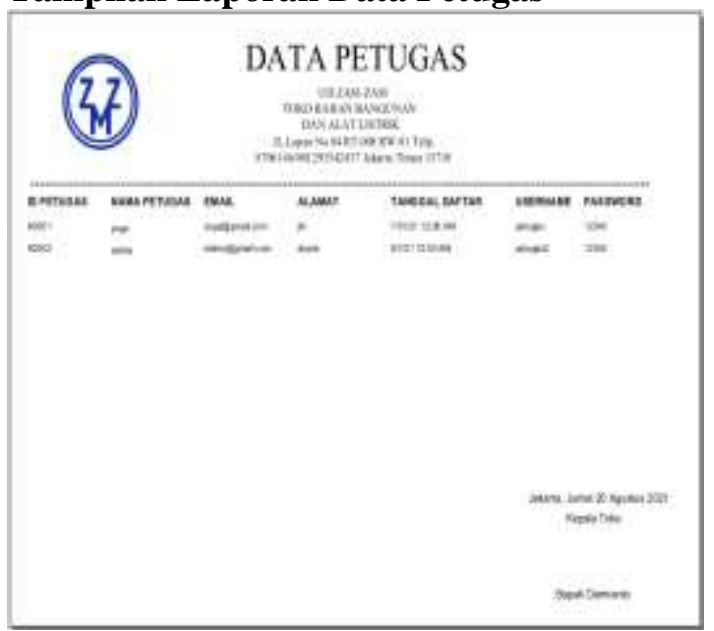

Gambar 17. Tampilan Laporan Data Petugas

Laporan data petugas ini digunakan untuk melihat data petugas yang ada pada Toko Bangunan UD.Zam-Zam. Dalam laporan data petugas ini terdapat logo, nama petugas, id petugas, email, alamat, tanggal daftar, username, password, tanggal pembuatan laporan dan nama dari pemilik toko itu sendiri. Laporan data petugas ini nantinya akan disimpan oleh admin sebagai berkas laporan yang telah dikeluarkan.

Tampilan Laporan Data Pelanggan

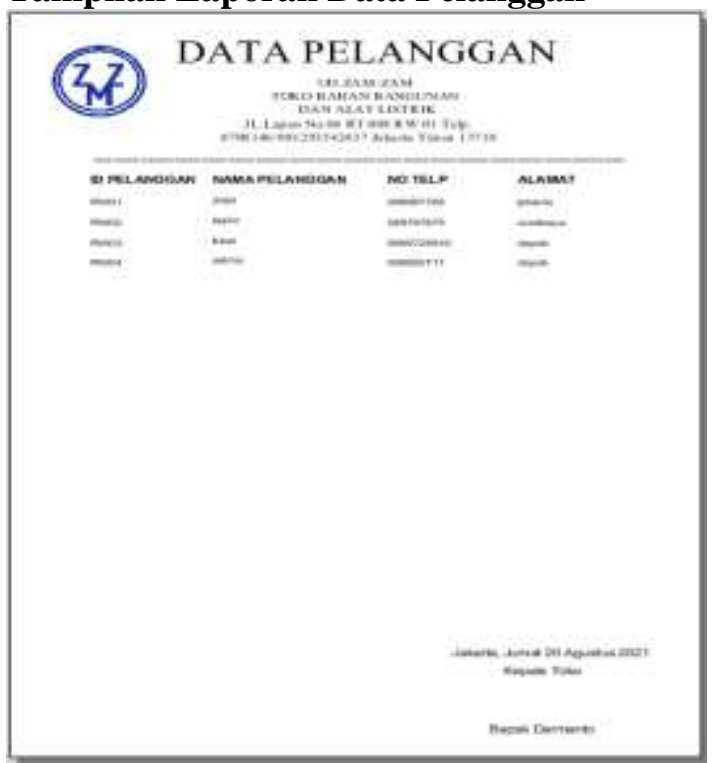

Gambar 18. Tampilan Laporan Data Pelanggan

Laporan data pelanggan ini digunakan untuk melihat data pelanggan yang ada pada Toko Bangunan UD.Zam-Zam. Dalam laporan data pelanggan ini terdapat logo, nama pelanggan, id pelanggan, no telp, alamat, tanggal pembuatan laporan dan nama dari pemilik toko itu sendiri. Laporan data pelanggan ini nantinya akan disimpan oleh petugas sebagai berkas laporan yang telah dikeluarkan.

\section{Tampilan Laporan Data Transaksi}

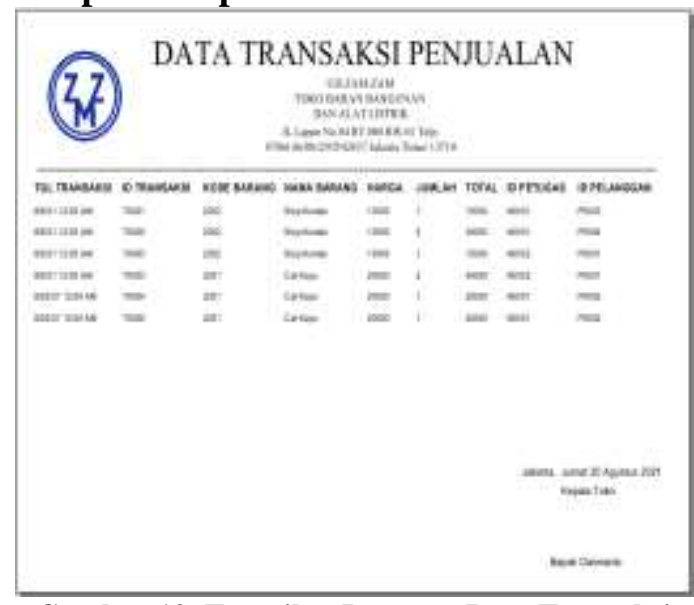

Gambar 19. Tampilan Laporan Data Transaksi

Laporan data transaksi ini digunakan untuk melihat data penjualan yang telah dilakukan pada Toko Bangunan UD.Zam-Zam. Dalam laporan data pelanggan ini terdapat logo, tgl transaksi, id transaksi, nama barang, kode barang, harga, jumlah, total, id petugas, id pelanggan, tanggal pembuatan laporan dan nama dari pemilik toko itu sendiri. Laporan data transaksi ini nantinya akan disimpan oleh admin sebagai berkas laporan yang telah dikeluarkan.

\section{Tampilan Struk Transaksi}

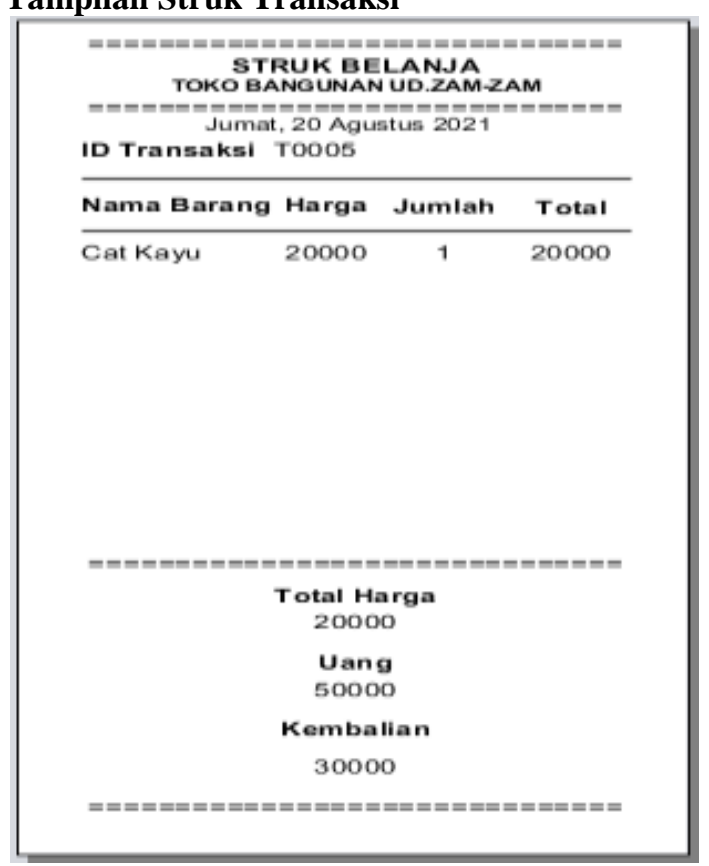

Gambar 20. Tampilan Struk Transaksi

Struk transaksi penjualan ini nantinya akan diserahkan kepada pelanggan ketika sudah 
melakukan transaksi pembelian di Toko Bangunan UD.Zam-Zam.

\section{SIMPULAN DAN SARAN}

Pembangunan sistem informasi penjualan ini dimaksudkan untuk dapat menangani petugas toko dalam melakukan penjualan secara cepat, akurat dan mempermudah untuk pengolahan data barang yang tidak lagi dilakukan secara manual tetapi menggunakan media berupa komputer. Sistem informasi penjualan yang dibuat masih harus diadakan evaluasi secara berkala agar aplikasi dapat dikembangkan dan dapat menjadi lebih baik untuk digunakan dengan penelitian atau analisa yang lebih spesifik dan melakukan pemeliharaan data dengan backup data secara berkala untuk mengantisipasi segala kemungkinan yang dapat terjadi terhadap kinerja sistem.

\section{DAFTAR PUSTAKA}

Andini, T. (2016). Aplikasi Pengolahan Data Aktivitas Institusi Pada Unit P3ai (Pusat Pengembangan Pendidikan Dan Aktivitas Instruksional) Politeknik Negeri Sriwijaya. Politeknik Negeri Sriwijaya.

Atmaja, R. A. R. (2020). Aplikasi Pemesanan Menu Pada Kafe Kopi Galau Berbasis Android. Senamika, 1(2), 647-654.

Kusuma, D. (2019). Sistem Monitoring Kualitas Air Sungai Di Area Sumateraselatan Dengan Metode Storet Padadinas Lingkungan Hidup Dan Pertanahan. Politeknik Negeri Sriwijaya.

Msi, P. D. S. (2012). Metodologi Penelitian: Metodologi Penelitian Model Prakatis Penelitian Kuantitatif Dan Kualitatif. Universitas Pendidikan Indonesia, 1243.

Novienty, L. D. (2016). Sistem Informasi Manajemen Sekolah Berbasis Web (Studi Kasus Sma Al Karimi Tebuwung). Jurnal Manajemen Informatika, 5(2).

Prasetya, D. A. P., Irawan, P., \& Sokibi, P. (2020). Rancang Bangun Sistem Pengarsipan Surat Kedinasan Berbasis Web Menggunakan Framework Codeigniter. Jurnal Manajemen Informatika Dan Sistem Informasi, 3(2), 157-165.

Sesunan, M. F. (2017). Perancangan Sistem Pembayaran Berobat Pasien Dipuskesmas Rawat Inap Kedaton
Bandar Lampung. Klik-Kumpulan Jurnal Ilmu Komputer, 1(1), 56-66.

Sipahutar, P. H. (2017). Peran Guru Mata Pelajaran Akidah Akhlak Dalam Pembinaan Akhlak Siswa Mas AlManaar Ujung Gurap Kelurahan Batunadua Kota Padangsidimpuan. Iain Padangsidimpuan.

Solihin, H. H., \& Nusa, A. A. F. (2017). Rancang Bangun Sistem Informasi Penjualan, Pembelian Dan Persediaan Suku Cadang Pada Bengkel Tiga Putra Motor Garut. Infotronik: Jurnal Teknologi Informasi Dan Elektronika, 2(2), 107-115.

Sukamto, R. A., \& Shalahuddin, M. (2018). Rekaya Perangkat Lunak. Bandung: Informatika Bandung.

Yanniar Afriendari, I. (2016). Tanggapan Pelanggan Terhadap Strategi Pemasaran Pengrajin Gitar Dan Bass Lokal K2 Di Yogyakarta. 